\title{
PENGARUH TINGGI DAN JARAK WAKTU PEMOTONGAN RUMPUT GAJAH DWARF (pannisetum purpureum $c v$. Mott) TERHADAP PERTUMBUHAN VEGETATIF DAN PRODUKSI BAHAN KERING
}

\author{
Santia, Selvie D. Anis*, Charles L. Kaunang
}

Fakultas Peternakan Universitas Sam Ratulangi Manado, 95115

\begin{abstract}
ABSTRAK
Penelitian ini bertujuan untuk mengetahui dan memperoleh data tentang pengaruh tinggi dan jarak waktu pemotongan rumput gajah dwarf (pannisetum purpureum $c v$. Mott). Perlakuan diatur secara faktorial dengan menggunakan Rancangan Acak Kelompok (RAK) yang terdiri dari 2 faktor dan 3 kali ulangan, dimana faktor A tinggi pemotongan, $\mathrm{a}_{1}=0 \mathrm{~cm}$ dari atas permukaan $\mathrm{a}_{2}=5 \mathrm{~cm}$ dari atas permukaan tanah $\mathrm{a}_{3}=10 \mathrm{~cm}$ dari atas permukaan tanah $\mathrm{a}_{4}=15 \mathrm{~cm}$ dari atas permukaan tanah. Faktor B umur pemotongan b1= 20 hari $\mathrm{b} 2=30$ hari, variabel yang diukur yaitu jumlah anakan, ratio daun/batang dan produksi bahan kering. Hasil analisis keragaman (Anova) menunjukkan jumlah anakan dan kadungan bahan kering rumput dipengaruhi sangat nyata $(\mathrm{P}<0,01)$ oleh interaksi perlakuan tinggi potong dan umur tanaman. Namun demikian umur tanaman memberikan pengaruh yang berbeda nyata $(\mathrm{P}<0,05)$ terhadap rasio daun batang.Sementara interaksi perlakuan tinggi potong dan umur tanaman tidak memberikan pengaruh berbeda nyata $(\mathrm{P}>0,05)$ terhadap rasio daun / batang. Berdasarkan hasil penelitian yang telah dilaksanakan dapat disimpulkan bahwa: Untuk menjamin kelanjutan produksi P.purpureum cv.Mott terukur pada jumlah anakan dan kandungan bahan kering sebaiknya dipotong pada umur 20 dan 30 hari dengan tinggi pemotongan $15 \mathrm{~cm}$ di
\end{abstract}

*Korespondensi (corresponding author)

Email: selvie_anis@yahoo.com atas permukaan tanah. Nilai rasio daun/batang yang tertinggi diperoleh pada umur pemotongan 20 hari.

Kata Kunci: P. purpureum cv. Mott, tinggi potong, umur potong,pertumbuhan, bahan kering.

\section{ABSTRACT}

\section{EFFECT OF HIGH AND DISTANCE OF CUTTING TIME OF DWARF ELEPHANT GRASS (pannisetum purpureum cv. Mott) ON VEGETATIVE GROWTH AND DRY MATERIAL PRODUCTION. This} research aims to identify and obtain data about the effect of height and distance of cutting time on vegetative growth and dry material production of dwarf elephant grass (pannisetum purpureum cv. Mott). The treatments were applied into factorial design on the base of Group Random Design (GRD) which consists of two factors and three replications. Factor A were cutting height, a $1=0 \mathrm{~cm}$ above the ground, $\mathrm{a}_{2}=5 \mathrm{~cm}$ above the ground, $\mathrm{a}_{3}=10$ $\mathrm{cm}$ above the ground, $\mathrm{a}_{4}=15 \mathrm{~cm}$ above the ground. Factor B age of cutting, b1 $=20$ days, and $\mathrm{b} 2=30$ days. The measured variables were including the number of tillers, ratio of leaf/stem and dry material production. Result of analysis of variance 
(ANOVA) showed that the number of tillers and dry ingredient of grass were affected very significantly $(\mathrm{P}<0,01)$ by the interaction of high of cutting and the age of plant. However, the age of plant was giving a significantly different effect $(\mathrm{P}<0,05)$ on the leaf/steam ratio. While the interaction high of cutting and age of plant did not significantly affect $(\mathrm{P}>0,05)$ the leaf/steam ratio. Based on the research, it can be concluded that I order to ensure the continued production of P.purpureum $c v$.Mott measured in the number of tillers and dry ingredient, it should be cut at the age of 20 and 30 days with a cutting height of $15 \mathrm{~cm}$ above ground level. The highest value of leaf/steam ratio was obtained at the cutting age of 20 days.

Keywords : P. purpureum cv. Mott, high and age of cutting, growth, dry material production

\section{PENDAHULUAN}

Hijauan pakan merupakan salah satu faktor penentu dalam pengembangan usaha peternakan khususnya untuk ternak ruminansia. Ketersediaan hijauan pakan yang tidak memadai baik kuantitas maupun kualitasnya, menjadi salah satu kendala dalam pengembangan usaha peternakan. Upaya untuk menyediakan hijauan pakan yang baik dan dapat terjamin kontinuitasnya sangat diperlukan. Salah satu upaya yang harus dilakukan adalah dengan penanaman hijauan pakan baik rumput maupun leguminosa disertai manajemen yang baik (Lasamadi et al., 2013). Salah satu hijauan pakan yang potensial dan sering diberikan pada ternak ruminansia adalah rumput gajah (Pennisetum purpureum cv. Mott). Rumput ini berumur panjang, tumbuh vertikal membentuk rumpun, daun lebat, dan bisa mencapai tinggi $2-2,5 \mathrm{~m}$. Produksi ratarata rumput gajah sekitar 250 ton/ha/tahun (Adiati et al. 1995). Rumput ini baik sebagai bahan silage, dan sebagai rumput potongan ataupun gembala, asal pertumbuhannya bisa dipertahankan pendek. Tanaman ini pertumbuhannya sangat cepat, dan waktu masih muda nilai gizinya cukup tinggi (Urribari et al., 2013). Itulah sebabnya maka dianjurkan untuk melakukan pemotongan pada saat tanaman itu masih muda/fase vegetatif (menjelang berbunga), karena tanaman ini mengambil zat makanan dari dalam tanah begitu cepat. Rumput gajah yang ada di Indonesia, yang belum banyak dikenal dan dibudidayakan adalah rumput gajah Dwarf (P. purpureum cv. Mott).

Rumput gajah Dwarf merupakan salah satu rumput unggul karena produksi kualitas cukup tinggi, palatable, mudah dibudidaya, tahan penyakit dan mampu beradaptasi pada kondisi lingkungan yang bervariasi (Kozioki et al., 2006). Namun demikian faktor manajemen pemotongan sangat perlu diperhatikan untuk mendapatkan produksi hijauan cukup dan berkualitas secara berkeseimbangan 
(Djajanegara, et al., 1998). Dalam hal ini Umur potong dan tinggi pemotongan akan berpengaruh pada hal tersebut di atas. Untuk itulah penelitian ini dilakukan untuk mempelajari bagaimana pengaruh faktor menajemen tersebut, yaitu fungsi pemotongan dan jarak waktu potong (umur tanaman) terhadap pertumbuhan vegetatif dan produk bahan kering.

\section{MATERI DAN METODE PENELITIAN}

\section{Tempat Dan Waktu Penelitian}

Penelitian ini telah dilaksanakan di lahan milik Balai Penelitian dan Pengembangan Pertanian di Desa Wori Kota Manado. Penelitian ini berlangsung selama 5 bulan yakni pada tanggal 16 Januari s/d 13 Mei 2016.

\section{Materi Penelitian}

Bahan. Bahan yang digunakan dalam penelitian ini yaitu Rumput Gajah Dwarf, air, tanah untuk penanaman, pupuk urea.

Alat. Alat yaitu, cangkul, skop, ember, gayung, selang, gunting, meter, pisau, tali raffia, paku, parang, sen plat, timbangan, gunting sen, penggaruk rumput,spidol, laptop, alat tulis menulis dan kamera untuk dokumentasi.

\section{Prosedur penelitian.}

Kegiatan persiapan yang dilakukan untuk penelitian ini adalah persiapan alat dan bahan dan persiapan lahan, sebagai berikut:

- Sebelum dilaksanakan penelitian harus mempersiapkan lahan terlebih dahulu, pembersihan dari gulma, membongkar menggemburkan dan meratakan tanah,

- Lahan yang telah dibersihkan di buat petak sebanyak 24 buah petak dengan ukuran masing-masing $2 \times 2$ meter. petak-petak tersebut kemudian dibagi dalam 3 kelompok, masing-masing kelompok berisi 8 petak. Petak-petak yang telah disiapkan, masing-masing akan ditanam menggunakan stek batang rumput gajah Dwarf yang telah disediakan ditanam pada masingmasing petak terdiri dari 25 stek batang rumput gajah Dwarf. Penanaman rumput gajah Dwarf dengan menggunakan stek batang panjang $30 \mathrm{~cm}$ dan memiliki 3-4 buku. Tiap petak dengan jarak tanam 0,50 .

- Setelah tanaman berumur satu bulan dua minggu, tanaman tersebut dipotong/didefoliasi untuk bertumbuh seragam dilakukan pemotongan sesuai perlakaun tinggi dan umur potong.

- setelah satu minggu tanaman akan diberi pupuk dasar urea $150 \mathrm{~kg} / \mathrm{ha}$. 
Setelah tanaman berumur satu bualan dilakukan pengambilan data pada setiap petak perlakuan. Pengambilan data dilakukan setip 20 dan 30 hari untuk melihat tingkat pertumbuhan jumlah anakan, ratio daun/batang dan akan diuji lanjut untuk mengetahui produksi bahan kering. Tanaman akan dipotong/caca, ditimbang dimasukkan kedalam kertas sampel dengan berat yang telah di tentukan dan di beri tanda masing-masing sesuai perlakuan.

- Setelah semua tanaman yang di potong/caca sesuai perlakuan yang telah dimasukan kedalam sampel yang berkisar 24 sampel dan masingmasing sampel berisi 300g, rumput tersebut dijemur pada terik matahari, sesudah menggunakan pengeringan melalui sinar matahari, rumput tersebut dimasukkan ke dalam oven selama 24 jam dengan suhu $70^{\circ} \mathrm{C}$, dikeluarkan dan ditimbang untuk mengetahui berat kering, selanjutnya dilakukan analisis laboratorium untuk mengetahui kandungan bahan keringnya.

\section{Variabel yang diukur}

Variabel yang diukur dalam penelitian ini adalah :

- Pertumbuhan vegetatif :

$\checkmark$ Jumlah anakan $\checkmark$ Ratio daun / batang

- Produksi bahan kering

\section{Rancangan Penelitian dan Analisis Data}

Penelitian ini menggunakan Rancangan Acak Kelompok (RAK) dengan pola faktorial yang terdiri dari 2 faktor dan 3 kali ulangan

Factor A adalah Tinggi pemotongan / Intensitas pemotongan

$\mathrm{a}_{1}=0 \mathrm{~cm}$ dari atas permukaan tanah $\mathrm{a}_{2}=5 \mathrm{~cm}$ dari atas permukaan tanah $\mathrm{a}_{3}=10 \mathrm{~cm}$ dari atas permukaan tanah $\mathrm{a}_{4}=15 \mathrm{~cm}$ dari atas permukaan tanah

Faktor B adalah umur pemotongan

$\mathrm{b}_{1}=20$ hari

$\mathrm{b}_{2}=30$ hari

dilakukan sebanyak 2 kali

Perlakuan diulang sebanyak 3 kali, dengan demikian terdapat 24 petak percobaan atau angka pengamatan. Data yang diperoleh dianalisis keragaman serta diuji lanjut dengan uji BNJ.

\section{HASIL DAN PEMBAHASAN}

\section{Jumlah anakan dan produksi bahan kering (BK)}

Hasil analisis keragaman (Anova) menunjukkan jumlah anakan dan kadungan bahan kering rumput 
Tabel 1. Pengaruh interaksi perlakuan terhadap jumah anakan dan kandungan bahan kering rumput $P$. purpureum cv. Mott

\begin{tabular}{ccc}
\hline Interaksi & Jumlah anakan & Bahan kering $(\%)$ \\
\hline $\mathrm{a}_{1} \mathrm{~b}_{1}$ & $11,33^{\mathrm{c}}$ & $15,16^{\mathrm{c}}$ \\
$\mathrm{a}_{1} \mathrm{~b}_{2}$ & $10,16^{\mathrm{c}}$ & $15,59^{\mathrm{c}}$ \\
$\mathrm{a}_{2} \mathrm{~b}_{1}$ & $13,01^{\mathrm{b}}$ & $15,52^{\mathrm{c}}$ \\
$\mathrm{a}_{2} \mathrm{~b}_{2}$ & $14,05^{\mathrm{b}}$ & $15,47^{\mathrm{c}}$ \\
$\mathrm{a}_{3} \mathrm{~b}_{1}$ & $15,50^{\mathrm{b}}$ & $19,37^{\mathrm{b}}$ \\
$\mathrm{a}_{3} \mathrm{~b}_{2}$ & $16,33^{\mathrm{b}}$ & $20,89^{\mathrm{b}}$ \\
$\mathrm{a}_{4} \mathrm{~b}_{1}$ & $19,00^{\mathrm{a}}$ & $23,08^{\mathrm{a}}$ \\
$\mathrm{a}_{4} \mathrm{~b}_{2}$ & $22,53^{\mathrm{a}}$ & $24,26^{\mathrm{a}}$ \\
\hline
\end{tabular}

Ket: Superskrip berbeda pada lajur sama.berbeda nyata $(\mathrm{P}<0,05)$

P.purpureum cv. Mott dipengaruhi sangat nyata $(\mathrm{P}<0,01)$ oleh interaksi perlakuan tinggi potong dan umur tanaman (Tabel 1).

Pada Tabel 1 menunjukkan bahwa jumlah anakan rumput P.purpureum $c v$. Mott sejalan dengan kandungan bahan kering, dimana interaksi antara tinggi pemotongan $15 \mathrm{~cm}$ dengan umur potong 20 hari dan 30 hari menghasilkan jumlah anakan terbanyak dan nyata $(\mathrm{P}<0,05)$ lebih banyak dibanding dengan interaksi tinggi pemotongan 0,5 dan $10 \mathrm{~cm}$ dengan umur potong 20 dan 30 hari, Hal ini dapat diterangkan bahwa pada umur potong 30 hari tanaman memiliki waktu yang cukup panjang untuk menghasilkan fotosintat melalui proses fotosintesis (Anis et al., 2014), dibanding dengan umur tanaman 20 hari. Selanjutnya pada tinggi potong $15 \mathrm{~cm}$ di atas permukaan tanah tanaman tersedia cukup banyak cadangan energi untuk menunjang pertumbuahan kembali terukur dalam bentuk anakan (Anis et al., 2016). Jumlah tunas/anakan merupakan indikator kemampuan hijauan pakan untuk bertumbuh kembali sekaligus sebagai tanda potensi menghasilkan biomasa yang tinggi. Demikian pula dengan hasil bahan kering, dimana interaksi tinggi potong 15 cm $\left(a_{4} b_{1}\right)$ dengan umur potong 20, dan dengan umur potong 30 hari $\left(\mathrm{a}_{4} \mathrm{~b}_{2}\right)$ memberikan hasil bahan kering tertinggi dibanding interaksi lainya. Hal ini terkait dengan umur tanaman 30 hari tersedia cukup panjang waktu fotosintesis untuk menghasilkan fotosintat sebagaimana yang terjadi pada variabel jumlah anakan.

\section{Rasio Daun / Batang}

Analisis sidik ragam menunjukkan bahwa interaksi perlakuan tinggi potong dan umur tanaman tidak memberikan pengaruh berbeda nyata $(\mathrm{P}>0,05)$ terhadap rasio daun/batang, 
Tabel 2. Nilai rasio daun/batang P.purpureum cv. Mott pada umur potong 20 dan 30 hari

\begin{tabular}{ccc}
\hline \multirow{2}{*}{ Ulangan } & \multicolumn{2}{c}{ Umur potong (hari) } \\
\cline { 2 - 3 } & 20 & 30 \\
\hline 1 & 1,40 & 1,12 \\
2 & 1,43 & 1,22 \\
3 & 1,56 & 1,38 \\
4 & 1,66 & 1,21 \\
\hline Rata rata & $1,51^{\mathrm{a}}$ & $1,23^{\mathrm{b}}$
\end{tabular}

Ket. Superskrip berbeda pada baris yang sama berbeda nyata $(\mathrm{P}<0.05)$

Namun demikian umur tanaman memberikan pengaruh yang berbeda nyata $(\mathrm{P}<0,05)$ terhadap rasio daun batang. Perlakuan umur tanaman 20 hari menghasilkan nilai rasio daun batang 1,51 nyata $(\mathrm{P}<0,05)$ lebih tinggi dibanding umur tanaman 30 hari hanya senilai 1,23.

Hal ini terjadi karena tanaman ini memiliki sifat tumbuh pada umur muda dengan komponen daun yang selalu lebih banyak dibandingkan komponen batang (Gomide et al., 2014).

\section{KESIMPULAN}

Berdasarkan hasil penelitian yang telah dilaksanakan dapat disimpulkan bahwa:

1. Untuk menjamin kelanjutan produksi P.purpureum cv.Mott terukur pada jumlah anakan dan kandungan bahan kering sebaiknya dipotong pada umur 20 dan 30 hari dengan tinggi pemotongan $15 \mathrm{~cm}$ di atas permukaan tanah.

2. Nilai rasio daun/batang yang tertinggi diperoleh pada umur pemotongan 20 hari.

\section{DAFTAR PUSTAKA}

Adiati, U., E. Soepeno, A. Handiwirawan, Gunawan dan D. Angreani. 1995. Pengaruh pemberian pupuk kandang terhadap produksi rumput gajah (pannisetum purpureum) di Kecamatan Puspo Kabupaten Pasuran. Prosiding Seminar Nasional Peternakan dan Veteriner, 7-8 November di Bogor, jilid 2:583-586.

Anis, S.D,, D.A. Kaligis, B. Tulung, and Aryanto, 2016. Leaf quality and yield of Gliricidia sepium (Jacq) stend under different population density and cutting interval in coconut plantation. Journal of the Indonesian Tropical Animal Agriculture. Vol.41(2): 91-98

Anis, S.D., M. Chozin, H..Soedarmadi, M. Ghulamadhi, dan Sudradjar. 2014. Keragaan pasture $B$. humudicola pada sistem pengembalaan dan stocking rate berbeda di lahan perkebunan 
kelapa. Jurnal pasture. Vol.3. no.2: 84-87

Djajanegara, A., M. Rangkuti., Siregar, Soedarsono, S.K. Sejati. 1998. Pakan ternak dan Faktor-faktornya. Pertemuan Ilmiah Ruminansia. Departemen Pertanian, Bogor.

Gomide, C. A. M., C.S. Chaves, K.G. Ribeiro, J.F. Morens. 2014. Struktural traits of elephant grass gemotypes under rotational stocking strategies. African Journal of Range and Forage pcienel. http://d×. doi. Org/10. 2989/ 10220119. 2014. 930929. Diakses 12 September 2016.

Kozioki, G. V., J. Porition, L. M. B. Sanchez. 2006. Influence of regrowth age on nutritive value of dwarf elephant grass (Pannisetum purpureum Schum cv. Mott) consumed by lamb. Journal of Animal feed Science, Vol. 119: 1-11.

Lasamadi, R. D., S.S. Malalantang, Rustandi, Selvie D. Anis. 2013. Pertumbuhan dan perkembangan rumput gajah Dwarf (Pannisetum purpureum cv. Mot) yang diberi pupuk organik hasil fermentasi EM4. Jurnal Zootek Vol 32. (5):

Steel, R.G.D. and J.H. Torrie. 1995. Prinsip dan Prosedur Statistika: Suatu Pendekatan Biometrik. Penerjemah: Sumantri, B. Gramedia Pustaka Utama, Jakarta.

Urribari. L., A. Ferrer. and A. Collina. 2003. Leaf protein from ammonia treasted dwarf elephant grass (Pannisetum purpureum Schum cv. Mott). Journal of Applied. Biochemistry and Biotechnology. Humana Press Inc. Vol. 122, no:1-3: 727-730. 